\title{
Effect of microparticulated whey proteins on milk coagulation properties
}

\author{
A. Sturaro, M. Penasa, M. Cassandro, A. Varotto, and M. De Marchi ${ }^{1}$ \\ Department of Agronomy, Food, Natural resources, Animals and Environment (DAFNAE), University of Padova, Viale dell'Università 16, \\ 35020 Legnaro (PD), Italy
}

\begin{abstract}
The enhancement of milk coagulation properties (MCP) and the reuse of whey produced by the dairy industry are of great interest to improve the efficiency of the cheese-making process. Native whey proteins (WP) can be aggregated and denatured to obtain colloidal microparticulated WP (MWP). The objective of this study was to assess the effect of MWP on MCP; namely, rennet coagulation time (RCT), curd-firming time, and curd firmness 30 min after rennet addition. Six concentrations of MWP (vol/vol; 1.5, 3.0, 4.5, 6.0, 7.5 , and $9.0 \%$ ) were added to 3 bulk milk samples (collected and analyzed during $3 \mathrm{~d}$ ), and a sample without MWP was used as control. Within each day of analysis, 6 replicates of MCP for each treatment were obtained, changing the position of the treatment in the rack. For control samples, 2 replicates per day were performed. In addition to MCP, WP fractions were measured on each treatment during the $3 \mathrm{~d}$ of analysis. Milk coagulation properties were measured on 144 samples by using a Formagraph (Foss Electric, Hillerød, Denmark). Increasing the amount of MWP added to milk led to a longer RCT. In particular, significant differences were found between RCT of the control samples (13.5 min) and RCT of samples with $3.0 \%$ (14.6 min) or more MWP. A similar trend was observed for curd-firming time, which was shortest in the control samples and longest in samples with 9.0\% MWP (21.4 min). No significant differences were detected for curd firmness at 30 min across concentrations of MWP. Adjustments in cheese processing should be made when recycling MWP, in particular during the coagulation process, by prolonging the time of rennet activity before cutting the curd.
\end{abstract}

Key words: microparticulated whey protein, milk coagulation property, dairy industry

Received March 21, 2014.

Accepted July 11, 2014.

${ }^{1}$ Corresponding author: massimo.demarchi@unipd.it

\section{INTRODUCTION}

The dairy industry has an important economic role in Italy and a main focus is the transformation of milk into high-quality cheeses. In this context, the evaluation of milk coagulation properties (MCP) is valuable to improve milk processing (Cassandro et al., 2008; De Marchi et al., 2008). Indeed, good technological properties of milk have been associated with enhanced cheese yield (Riddell-Lawrence and Hicks, 1989; Pretto et al., 2013). Several instruments can be used to measure MCP (O'Callaghan et al., 2002), and mechanical tools such as the Formagraph (Foss Electric, Hillerød, Denmark) have been widely used to determine MCP. These instruments produce a typical diagram as reported by De Marchi et al. (2009) and provide measurement of rennet coagulation time (RCT), curd-firming time, and curd firmness $30 \mathrm{~min}$ after rennet addition. Recently, mid-infrared spectroscopy combined with chemometric analysis has been proposed as fast, nondestructive, and cheap technique to predict MCP (De Marchi et al., 2013, 2014; Tiezzi et al., 2013).

At present, improvements in the efficiency of the dairy industry are needed. The recovery of whey protein (WP) after cheese-making process is an interesting application. Native WP can be extracted from whey through filtration to obtain WP concentrate (WPC), which is further aggregated and denatured through a controlled process to produce colloidal microparticulated WP (MWP; Spiegel and Huss, 2002). In addition, the dairy industry faces growing demand for low-fat products; in this context, the incorporation of WPC and MWP as fat replacer into milk to maintain the yield and nutritional value of dairy products can be an efficient solution (Lo and Bastian, 1998). Microparticulated WP has been used to improve overall sensory properties of low-fat dairy products such as ice cream (Yilsay et al., 2006; Karaca et al., 2009), yogurt (Janhøj et al., 2006; Aziznia et al., 2008; Torres et al., 2011), and cheeses (Koca and Metin, 2004; Sahan et al., 2008; Ismail et al., 2011). Substitution of fat with MWP reduces the firmness of low-fat products because of the water-holding capacity of MWP. Excessive addition of WP is likely to interfere with curd formation and adversely affect cheese quality (Guinee et al., 1998). 
The aggregation of MWP is influenced by WP composition, the presence of lactose or $\kappa-\mathrm{CN}$ (Guyomarc'h et al., 2009), heat treatment, $\mathrm{pH}$, and ionic strength conditions (Chen et al., 2006; Nicolai and Durand, 2007; Gulzar et al., 2011). There is a paucity of studies investigating the effect of the addition of WP to milk. Ismail et al. (2011) reported shorter RCT of buffalo milk with added WPC, whereas Guinee et al. (1997) found impaired renneting properties of bovine milk with added WPC. Interest in valorizing whey components and improving MCP during cheese making is high in a dairy industry specializing in cheese production. Therefore, the aim of the present study was to investigate the effect of increasing concentrations of MWP (from 0.0 to $9.0 \%, \mathrm{vol} / \mathrm{vol})$ on MCP.

\section{MATERIALS AND METHODS}

\section{Sample Collection and Experimental Design}

Three samples of raw bulk milk were collected from 3 farms of the Veneto region (northeast Italy) during 3 sampling dates in October 2012. Milks were stored in a portable refrigerator $\left(4^{\circ} \mathrm{C}\right)$ and analyzed within $1 \mathrm{~h}$ in the milk quality laboratory of the Breeders Association of Veneto region (ARAV, Padova, Italy) for fat, protein, CN, and lactose contents using a MilkoScan FT6000 (Foss Electric, Hillerød, Denmark).

Microparticulated WP was collected in the Soligo dairy cooperative (Farra di Soligo, Treviso, Italy) at the beginning of the trial, and it was used for all the sessions. On the days of analysis, aliquots of MWP were stored at $-20^{\circ} \mathrm{C}$. Microparticulated WP was extracted from total skim sweet whey produced by the dairy cooperative in a working day through the ultrafiltration process (Tetrapak International SA, Rubiera, Italy), using a tubular semipermeable polyethersulfone membrane with a surface area of $700 \mathrm{~m}^{2}$, and a cut-off of 10,000 Da (6338 HFK-131; Koch Membrane System, Wilmington, MA) at $10^{\circ} \mathrm{C}$. Moreover, the microparticulation process was carried out for $10 \mathrm{~min}$ at $95^{\circ} \mathrm{C}$ by using a shell-and-tube heat exchanger and homogenization at $4,000 \mathrm{kPa}$ following the manufacturer's protocols (Tetrapak International SA).

Microparticulated WP were added at increasing concentrations $(1.5,3.0,4.5,6.0,7.5$, and $9.0 \%$; vol/ vol) to bulk milk. A sample without MWP (MWP = $0.0 \%$ ) was used as control. Within each day of analysis, 6 replicates of MCP for each treatment were obtained, changing the position of the treatment in the rack. For the control samples, 2 replicates per day were performed. In addition to MCP, WP fractions were measured on each treatment during the $3 \mathrm{~d}$ of analysis.

\section{Analysis of MWP}

Microparticulated whey protein fractions were quantified by reverse-phase (RP)-HPLC after solubilization with $6 M$ guanidine hydrochloride (Sigma, St. Louis, MO) for $24 \mathrm{~h}$. Reverse-phase HPLC analysis was carried out in the laboratory of the Department of Agronomy, Food, Natural Resources, Animals and Environment of the University of Padova (Legnaro, Italy) using an Agilent 1260 Series chromatograph instrument (Agilent Technologies, Santa Clara, CA), and separation was performed on a reversed-phase analytical column C8 (Zorbax 300SB-C8 RP, Agilent Technologies) with a Poroshell packing $(5 \mu \mathrm{m}, 300 \AA, 2.1 \times 75 \mathrm{~mm})$. Detection was at $214 \mathrm{~nm}$. Gradient elution was carried out with a mixture of 2 solvents: solution A consisted of $0.1 \%$ trifluoroacetic acid and $5 \%$ acetonitrile in water, and solution B was $0.1 \%$ trifluoroacetic acid in acetonitrile. The gradient started with $95 \%$ of solution A, after 1 min the gradient was $82 \%$ of $\mathrm{A}$, after $2 \mathrm{~min}$ it was $70 \%$, and after 5 min $\mathrm{A}$ and $\mathrm{B}$ were in equilibrium. From 5 to $9 \mathrm{~min}$ (end of the run), the gradient was brought back to initial conditions (95\% A). Quantified WP were $\alpha-\mathrm{LA}, \beta-\mathrm{LG} \mathrm{A}$ and $\beta-\mathrm{LG} \mathrm{B}$ variants, BSA, lactoferrin (LF), caseinomacropeptide (CMP), and proteose-peptone $(\mathbf{P P})$.

\section{Analysis of MCP}

Aliquots of daily milk and serial percentage of MWP were mixed within each day of the trial and kept at $4^{\circ} \mathrm{C}$ until the beginning of the analysis. A final volume of $10 \mathrm{~mL}$ for each sample was heated to $35^{\circ} \mathrm{C}$ in 10 min; once $35^{\circ} \mathrm{C}$ was reached, $200 \mu \mathrm{L}$ of rennet (Hansen standard 190, Pacovis Amrein AG, Bern, Switzerland) diluted $1.6 \%$ with distilled water was added to milk (Pretto et al., 2013). In total, 144 measures of MCP were determined using a Formagraph (Foss Electric). The working principle of the Formagraph is based on the swing of a pendulum immersed in milk and driven by an electromagnetic field. As the cheese milk coagulates, the swing of the pendulum becomes smaller and differences in the electromagnetic field are recorded (O'Callaghan et al., 2002). The output of the instrument consists of 3 measurements of MCP: RCT (min), defined as the interval from the addition of the clotting enzyme to the beginning of coagulation; curdfirming time $\left(\mathbf{k}_{\mathbf{2 0}}, \mathrm{min}\right)$, which is the interval from the beginning of coagulation to the time at which the width of the graph attains $20 \mathrm{~mm}$; and curd firmness $\left(\mathbf{a}_{\mathbf{3 0}}, \mathrm{mm}\right)$, defined as the width of the diagram $30 \mathrm{~min}$ after rennet addition. 


\section{Whey Sample Collection and Analysis}

Whey was collected after manual cross-cut, using a bistoury, of the curd immediately after the end of MCP analysis. Whey from all replicates of the same treatment $(\mathrm{n}=21)$ was combined and WP fractions were identified using RP-HPLC, as previously described for MWP analysis. Quantified WP $(\mathrm{mg} / \mathrm{mL})$ were $\alpha$-LA, $\beta$-LG A, $\beta$-LG B, BSA, LF, CMP, and PP. Microparticulated WP losses $\left(\mathrm{MWP}_{\text {losses }}, \%\right)$ were calculated for each fraction as follows:

$$
\mathrm{MWP}_{\text {losses }}=\left(\mathrm{WP}_{\text {treatment }} / \mathrm{WP}_{\mathrm{MWP}}\right) \times 100,
$$

where $\mathrm{WP}_{\text {treatment }}$ is the $\mathrm{WP}$ fraction in each MWP treatment sample and $\mathrm{WP}_{\mathrm{MWP}}$ is the $\mathrm{WP}$ fraction added to milk through MWP.

\section{Statistical Analysis}

Data of MCP, WP fractions, and MWP losses were analyzed through the general linear model (GLM) procedure (SAS Institute Inc., Cary, NC). The linear model for MCP included the fixed effects of MWP concentration (7 levels), day of analysis (3 levels), replicate (6 levels), and interaction between MWP concentration and day of analysis, and the random effect of residual. The model for WP fractions and MWP losses included the fixed effects of MWP concentration $(7$ and 6 levels, respectively), and day of analysis (3 levels), and the random effect of residual. A multiple comparison of means was performed for the main effect of MWP, using the Bonferroni test $(P<0.05)$.

\section{RESULTS}

\section{MCP}

Means (standard deviation) of fat, protein, $\mathrm{CN}$, and lactose contents of raw bulk milk used during the whole trial were $2.73 \%(0.82), 3.70 \%(0.15), 2.77 \%$ (0.04), and $4.87 \%(0.05)$, respectively. Rennet coagulation time, $\mathrm{k}_{20}$, and $\mathrm{a}_{30}$ averaged $14.7 \mathrm{~min}, 20.1 \mathrm{~min}$, and 35.5 $\mathrm{mm}$, respectively, and the coefficient of variation $(\mathbf{C V})$ was $16.3 \%$ for RCT, $14.8 \%$ for $\mathrm{k}_{20}$, and $18.1 \%$ for $\mathrm{a}_{30}$, indicating that the variability among MCP was similar (Table 1).

Results from the ANOVA for MCP are summarized in Table 2. The coefficient of determination $\left(\mathrm{R}^{2}\right)$ was 0.80 for RCT, 0.71 for $\mathrm{k}_{20}$, and 0.63 for $\mathrm{a}_{30}$. The concentration of MWP, day of analysis, and replicate effects were highly significant $(P<0.001)$ in explaining the variation of RCT and $\mathrm{k}_{20}$. Curd firmness was significantly ( $P$ $<0.01$ ) affected by day of analysis and replicate, but not by concentration of MWP $(P=0.23)$. Finally, the influence of fixed interaction effect between MWP and day of analysis was statistically negligible for all $\mathrm{MCP}$ $(P>0.05$; Table 2).

Figure 1 depicts the least squares means of MCP across concentrations of MWP. Increasing the amount

Table 1. Descriptive statistics of milk coagulation properties, whey protein (WP) fractions, and microparticulated whey protein (MWP) losses

\begin{tabular}{|c|c|c|c|c|c|}
\hline Trait & $\begin{array}{c}\text { No. of } \\
\text { samples }\end{array}$ & Mean & $\mathrm{SD}$ & Minimum & Maximum \\
\hline \multicolumn{6}{|c|}{ Milk coagulation property ${ }^{1}$} \\
\hline $\mathrm{RCT}, \min$ & 144 & 14.7 & 2.39 & 10.3 & 22.3 \\
\hline $\mathrm{k}_{20}, \min$ & 144 & 20.1 & 2.98 & 14.5 & 28.2 \\
\hline $\mathrm{a}_{30}, \mathrm{~mm}$ & 144 & 35.5 & 6.44 & 18.0 & 48.0 \\
\hline \multicolumn{6}{|l|}{ WP fraction, $\mathrm{mg} / \mathrm{mL}$} \\
\hline$\alpha-\mathrm{LA}$ & 21 & 0.68 & 0.09 & 0.21 & 0.78 \\
\hline$\beta-L G$ A & 21 & 3.43 & 0.35 & 2.28 & 4.03 \\
\hline$\beta-L G$ B & 21 & 1.66 & 0.10 & 1.45 & 1.79 \\
\hline BSA & 21 & 0.13 & 0.03 & 0.05 & 0.02 \\
\hline Lactoferrin & 21 & 0.03 & 0.02 & 0.01 & 0.06 \\
\hline Caseinomacropeptide & 21 & 0.94 & 0.16 & 0.73 & 1.27 \\
\hline Proteose-peptone & 21 & 0.28 & 0.05 & 0.17 & 0.36 \\
\hline \multicolumn{6}{|l|}{ MWP loss, ${ }^{2} \%$} \\
\hline$\alpha-L A$ & 18 & 92.6 & 3.37 & 85.9 & 97.9 \\
\hline$\beta-L G$ A & 18 & 89.1 & 6.67 & 75.0 & 99.6 \\
\hline$\beta$-LG B & 18 & 59.6 & 3.80 & 54.5 & 67.1 \\
\hline BSA & 18 & 65.8 & 16.2 & 38.2 & 81.5 \\
\hline Lactoferrin & 18 & 62.4 & 15.2 & 48.7 & 79.1 \\
\hline Caseinomacropeptide & 18 & 22.0 & 3.28 & 16.0 & 28.0 \\
\hline Proteose-peptone & 18 & 17.4 & 2.81 & 12.4 & 21.7 \\
\hline
\end{tabular}

${ }^{1} \mathrm{RCT}=$ rennet coagulation time; $\mathrm{k}_{20}=$ curd-firming time; $\mathrm{a}_{30}=$ curd firmness 30 min after rennet addition.

${ }^{2}$ Calculated as $\left(\mathrm{WP}_{\text {treatment }} / \mathrm{WP}_{\mathrm{MWP}}\right) \times 100$, where $\mathrm{WP}_{\text {treatment }}$ is $\mathrm{WP}$ fraction in each MWP treatment and $\mathrm{WP}_{\mathrm{MWP}}$ is WP fraction added to milk through MWP. 
Table 2. Results from ANOVA ( $F$-value and significance) for milk coagulation properties

\begin{tabular}{|c|c|c|c|c|c|c|}
\hline \multirow[b]{2}{*}{ Trait $^{1}$} & \multicolumn{4}{|c|}{ Effect } & \multirow[b]{2}{*}{$\mathrm{RMSE}^{3}$} & \multirow[b]{2}{*}{$\mathrm{R}^{2}$} \\
\hline & $\mathrm{MWP}^{2}$ & Day & Replicate & MWP $\times$ Day & & \\
\hline $\mathrm{RCT}, \min$ & $14.3^{* * *}$ & $157.0^{* * *}$ & $10.3^{* * *}$ & 0.47 & 1.17 & 0.80 \\
\hline $\mathrm{k}_{20}, \min$ & $6.9 * * *$ & $96.5^{* * *}$ & $5.9^{* * *}$ & 0.63 & 1.77 & 0.71 \\
\hline $\mathrm{a}_{30}, \mathrm{~mm}$ & 0.23 & $83.8^{* * *}$ & $3.3^{* *}$ & 0.31 & 4.32 & 0.63 \\
\hline
\end{tabular}

of MWP added to milk led to longer RCT. In particular, significant differences $(P<0.05)$ were found between RCT of the control samples (13.5 min) and samples with $3.0 \%$ (14.6 min) or more MWP. Also, milk with 9.0\% MWP exhibited longer RCT (16.0 min) than samples with $4.5 \%$ (14.8 min) or less MWP $(P<$ $0.05)$. A similar trend was observed for $\mathrm{k}_{20}$, which was shortest in the control samples (18.9 min) and longest in samples with $9.0 \%$ (21.4 min) MWP (Figure 1). Statistically significant differences $(P<0.05)$ were found between control and samples with $6.0 \%$ (20.9 min) or more MWP, and between samples with 1.5\% (19.1 min) and those with more than $7.5 \%$ (21.2 min) MWP. In contrast to RCT and $\mathrm{k}_{20}$, no significant differences $(P$ $>0.05)$ were detected for $\mathrm{a}_{30}$ across concentrations of MWP. However, the tendency was for a weaker gel moving from control $(36.1 \mathrm{~mm})$ to samples with $7.5 \%$ $(34.9 \mathrm{~mm})$ and $9.0 \%$ (35.1 mm) MWP (Figure 1).

\section{WP Fractions and MWP Losses}

The average quantity of WP fractions ranged from $0.03 \mathrm{mg} / \mathrm{mL}$ for LF to $3.43 \mathrm{mg} / \mathrm{mL}$ for $\beta$-LG A, and the CV ranged from $6.1 \%$ ( $\beta$-LG B) to $55.7 \%$ (LF; Table $1)$. Average losses of MWP varied from $17.4 \%(\mathrm{PP})$ to $92.6 \%(\alpha-\mathrm{LA})$, and the $\mathrm{CV}$ ranged from $3.6 \%$ ( $\alpha-\mathrm{LA})$ to $24.7 \%$ (BSA; Table 1).

Results from the ANOVA for WP fractions and MWP losses are summarized in Table 3. Coefficients of determination of the models for WP fractions ranged from 0.46 $(\alpha-\mathrm{LA})$ to $0.89(\mathrm{PP})$, and those for MWP losses ranged from 0.58 (LF) to 0.88 ( $\beta$-LG B). The day of analysis was significant $(P<0.01)$ in explaining the variability of $\beta-\mathrm{LG}$ B, BSA, and PP, both in whey and MWP losses, and it was important in explaining the variation of $\mathrm{LF}$ in whey and $\beta$-LG A in MWP losses $(P<0.01)$. The effect of MWP was important $(P<0.05)$ in explaining the variability of CMP and PP fractions, both in whey and MWP losses. Moreover, the MWP effect was important $(P<0.05)$ for $\beta$-LG B and BSA fractions in whey, and for $\alpha$-LA in MWP losses (Table 3).
Least squares means of WP fractions and MWP losses across concentrations of MWP are given in Table 4. The percentage of $\alpha-\mathrm{LA}, \beta-\mathrm{LG} \mathrm{A}$, and BSA in whey tended to decrease when moving from zero (control samples) to 9.0\% MWP in milk, but no statistical significance was observed $(P>0.05)$. Lactoferrin showed $(P>0.05)$ an inconsistent trend across MWP. A significant reduction of $\beta$-LG B from 1.75 to $1.58 \mathrm{mg} / \mathrm{mL}(P<0.05)$ was observed comparing control samples and samples with 9.0\% MWP, whereas no differences were detected $(P$ $>0.05)$ for concentrations of MWP between 1.5 and $7.5 \%$ (Table 4). Significant increments of CMP and PP were observed in whey when moving from zero to $9.0 \%$ MWP $(P<0.05)$; in particular, CMP increased from 0.76 to $1.15 \mathrm{mg} / \mathrm{mL}$, and PP from 0.22 to $0.34 \mathrm{mg} /$ $\mathrm{mL}$. Microparticulated whey losses of $\alpha$-LA and BSA decreased when comparing samples with 1.5 and $9.0 \%$ MWP, albeit not significantly $(P>0.05$; Table 4$)$. In contrast, MWP losses of LF, CMP, and PP were higher in milk with a high percentage of MWP; in the case of CMP and PP, the losses increased from 17.7 to $25.2 \%$ and from 13.7 to $19.9 \%$, respectively, when moving from samples with $1.5 \%$ to samples with $9.0 \%$ MWP $(P<0.05$; Table 4).

\section{DISCUSSION}

\section{Effect of MWP on MCP}

Milk composition is the main factor that influences MCP (Politis and Ng-Kwai-Hang, 1988; Formaggioni et al., 2001). Raw bulk milk used for MCP analysis exhibited higher protein and CN percentages, and lower fat percentage than vat milk (De Marchi et al., 2008). However, mean values for protein and $\mathrm{CN}$ percentages of the present work were comparable to the findings of Penasa et al. (2014) on milk from multi-breed dairy herds. Protein and CN contents are positively related to milk coagulation ability (Pretto et al., 2013) and are crucial in determining cheese yield (Summer et al., 2002). 

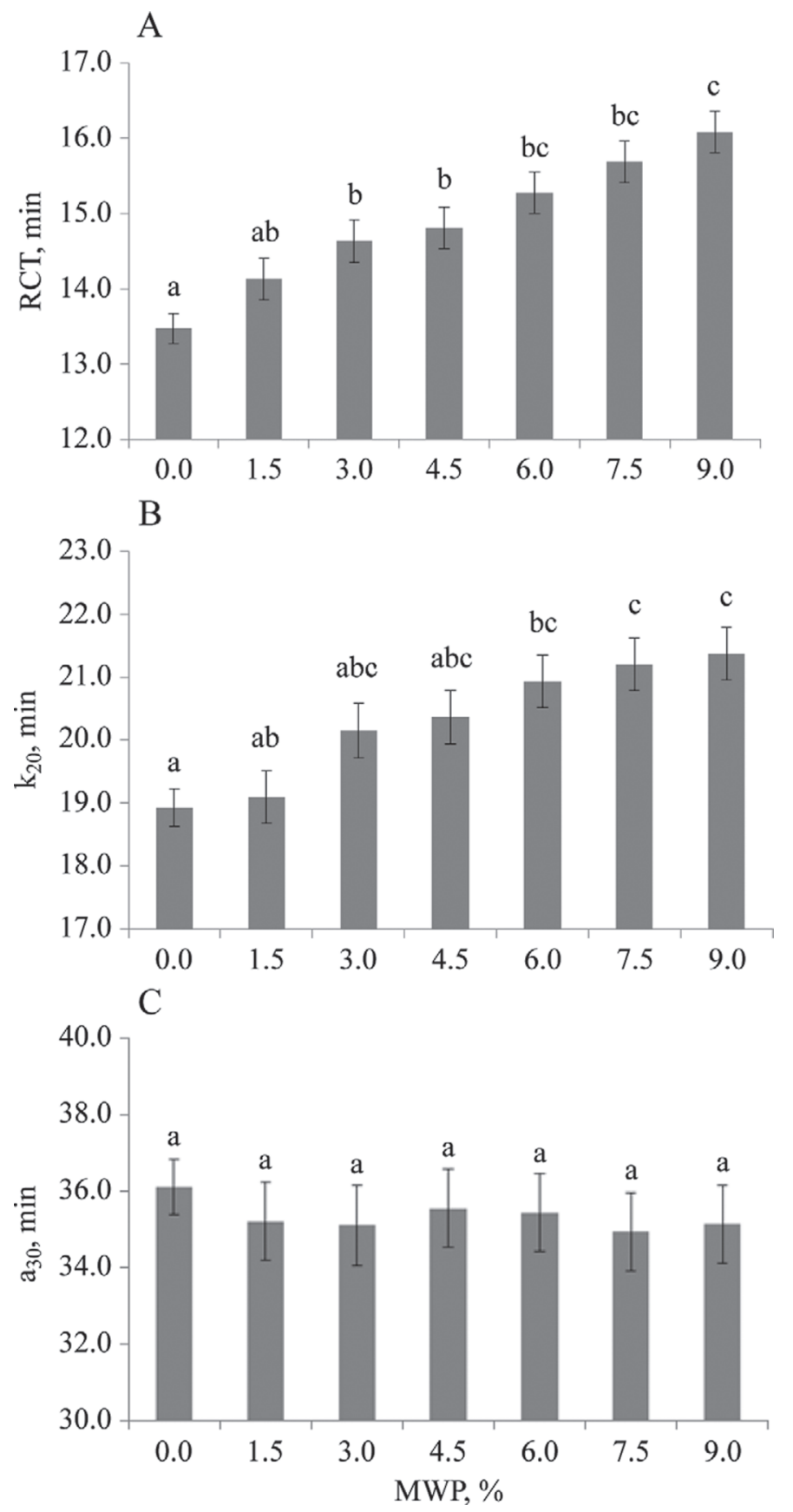

Figure 1. Least squares means $( \pm \mathrm{SE})$ of $(\mathrm{A})$ rennet coagulation time (RCT, min); (B) curd-firming time $\left(\mathrm{k}_{20}, \mathrm{~min}\right)$; and (C) curd firmness 30 min after rennet addition $\left(\mathrm{a}_{30}, \mathrm{~mm}\right)$ across different concentrations of microparticulated whey proteins (MWP: 0.0, 1.5, 3.0, 4.5, 6.0, 7.5 , and $9.0 \% \mathrm{vol} / \mathrm{vol})$. Least squares means with different letters $(\mathrm{a}-\mathrm{c})$ are significantly different according to Bonferroni's test $(P<0.05)$.

Several other factors affect MCP, the most important of which are stage of lactation, breed of cow (De Marchi et al., 2007; Penasa et al., 2014), casein genotypes (Ikonen et al., 1999; Comin et al., 2008; Penasa et al., 2010), and additive polygenic effects (Ikonen et al., 2004;
Cassandro et al., 2008; Tiezzi et al., 2013). The average values of MCP from the present study were difficult to compare with those reported in the literature because of the use of MWP. Control milk coagulated $0.65 \mathrm{~min}$ earlier than milk with $1.5 \%$ MWP, and a progressive deterioration of RCT was observed by increasing the percentage of MWP. A similar pattern was reported by Guinee et al. (1997), who used a commercial WPbased ingredient. However, the weak gel formation in Guinee et al. (1997) was probably related to the use of modified pasteurization of milk, which increased WP denaturation. Indeed, increasing the temperature of pasteurization promotes the complex formation between denatured WP and $\mathrm{CN}$, with the concomitant reduction in accessibility of the rennet to the CN (Rynne et al., 2004). In contrast to the present study, the addition of WP to buffalo milk shortened RCT in the work of Ismail et al. (2011). This was probably related to the higher acidity content of WP that increased the acidity of milk. The aforementioned effect could be due to type of WP used by Ismail et al. (2011), which was derived from whey immediately after cheese making. Regarding $\mathrm{k}_{20}$, Guinee et al. (1997) observed a reduction of the time to attain $20 \mathrm{~mm}$ of firmness using MWP, which is opposite to the trend reported in our research.

Microparticulated WP is widely used in low-fat products to maintain smoothness. The combined effect of MWP addition and heat treatment on MCP decreases the degree of $\mathrm{CN}$ aggregation during curd formation and may therefore have the potential to improve the texture of low-fat products by imparting a softening effect for the higher moisture content (Yilsay et al., 2006; Sahan et al., 2008; Torres et al., 2011).

\section{Effect of MWP on WP Fractions and MWP Losses}

The identified WP, listed according to their contents in whey, were $\beta$-LG A, $\beta$-LG B, CMP, $\alpha$-LA, PP, BSA, and LF, as reported in other studies (de Wit, 1998; Casal et al., 2006). Protein fractions such as $\beta-L G$ A, $\beta$-LG B, and $\alpha$-LA showed trends to decrease with increasing concentrations of MWP in milk. It is known that $\alpha-\mathrm{LA}$ and $\beta-\mathrm{LG}$ can adhere to the surface of casein micelles through formation of WP-k-CN complexes (Lucey et al., 1998). In contrast, peptides do not embed in the aggregate microparticles, increasing their loss in whey, as reported in the present work for CMP and PP. It is well documented that whey composition affects aggregation of MWP (Guyomarc'h et al., 2009).

The efficiency of MWP recovery depends on the denaturation degree of WP obtained in the MWP process. Denatured proteins obstruct syneresis and, thus, less water drains off during the cheese-making process. Moreover, an advantage in the use of denatured WP is 
Table 3. Results from ANOVA ( $F$-value and significance) for whey protein $(\mathrm{WP})$ fractions and microparticulated whey protein (MWP) losses

\begin{tabular}{|c|c|c|c|c|}
\hline \multirow[b]{2}{*}{ Trait } & \multicolumn{2}{|c|}{ Effect } & \multirow[b]{2}{*}{$\mathrm{RMSE}^{2}$} & \multirow[b]{2}{*}{$\mathrm{R}^{2}$} \\
\hline & $\mathrm{MWP}^{1}$ & Day & & \\
\hline \multicolumn{5}{|l|}{ WP fraction, $\mathrm{mg} / \mathrm{mL}$} \\
\hline$\alpha-\mathrm{LA}$ & 1.43 & 0.01 & 0.10 & 0.46 \\
\hline$\beta-L G A$ & 1.40 & 2.90 & 0.30 & 0.54 \\
\hline$\beta-L G$ B & $3.49^{*}$ & $28.8^{* * *}$ & 0.05 & 0.87 \\
\hline BSA & $3.56^{*}$ & $9.51^{* *}$ & 0.02 & 0.77 \\
\hline Lactoferrin & 1.10 & $23.2^{* * *}$ & 0.01 & 0.82 \\
\hline Caseinomacropeptide & $8.4^{* *}$ & 0.14 & 0.09 & 0.81 \\
\hline Proteose-peptone & $12.4^{* *}$ & $13.8^{* *}$ & 0.02 & 0.89 \\
\hline \multicolumn{5}{|l|}{ MWP loss, $\%$} \\
\hline$\alpha-\mathrm{LA}$ & $3.95^{*}$ & 1.97 & 2.40 & 0.70 \\
\hline$\beta-\mathrm{LG} \mathrm{A}$ & 2.31 & $23.6^{* *}$ & 3.32 & 0.85 \\
\hline$\beta-L G$ B & 1.80 & $32.7^{* * *}$ & 1.71 & 0.88 \\
\hline BSA & 1.73 & $9.01^{* *}$ & 11.0 & 0.73 \\
\hline Lactoferrin & 2.21 & 1.41 & 12.8 & 0.58 \\
\hline Caseinomacropeptide & $5.38^{*}$ & 0.12 & 2.22 & 0.73 \\
\hline Proteose-peptone & $8.84^{* *}$ & $9.78^{* *}$ & 1.35 & 0.86 \\
\hline
\end{tabular}

${ }^{1}$ Concentration of MWP ( $\left.\mathrm{vol} / \mathrm{vol}\right)$.

${ }^{2} \mathrm{RMSE}=$ root mean square error.

${ }^{3}$ Calculated as $\left(\mathrm{WP}_{\text {treatment }} / \mathrm{WP}_{\mathrm{MWP}}\right) \times 100$, where $\mathrm{WP}_{\text {treatment }}$ is $\mathrm{WP}$ fraction in each $\mathrm{MWP}$ treatment and $\mathrm{WP}_{\mathrm{MWP}}$ is WP fraction added to milk through MWP

${ }^{*} P<0.05 ;{ }^{* *} P<0.01 ; * * * P<0.001$.

that they can be inserted inertly into the pores of the CN network similarly to fat globules, whereas undenatured WP would be lost in the whey. However, larger particles disturb the homogeneity of the network and result in a reduction of firmness (Hinrichs, 2001). Slight differences were observed for MWP losses, in particular $\alpha$-LA and BSA, which showed a reduction in WP loss, increasing MWP. The positive effects of $\beta$-LG on gelation properties have recently been reported by de Faria et al. (2013), confirming the higher quality of gels produced with a high proportion of $\beta-\mathrm{LG}$ compared with materials produced with higher CMP. Similar results were reported by Roufik et al. (2005) for BSA and $\alpha-\mathrm{LA}$.

Table 4. Least squares means of whey protein (WP) fractions and microparticulated whey protein (MWP) losses across different concentrations of MWP (0.0 to $9.0 \%)$

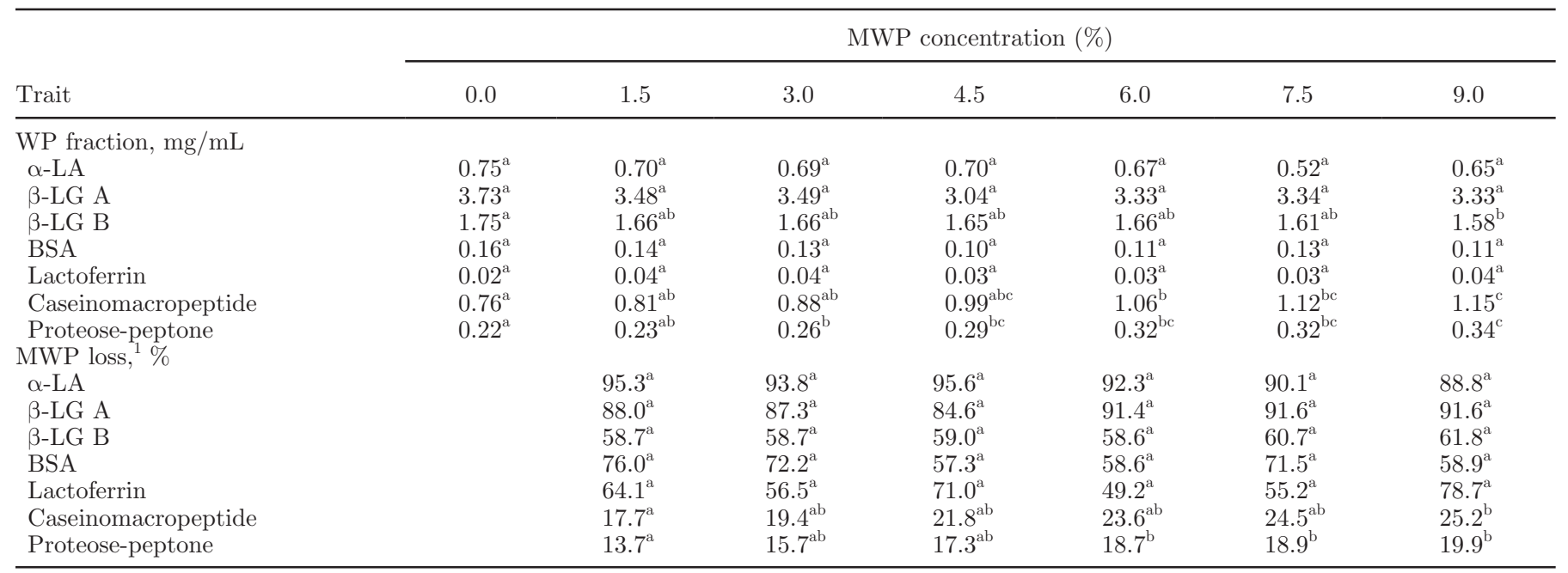

${ }^{\mathrm{a}-\mathrm{c}}$ Least squares means with different letters within a row are significantly different according to Bonferroni's test $(P<0.05)$.

${ }^{1}$ Calculated as $\left(\mathrm{WP}_{\text {treatment }} / \mathrm{WP}_{\mathrm{MWP}}\right) \times 100$, where $\mathrm{WP}_{\text {treatment }}$ is WP fraction in each MWP treatment and $\mathrm{WP}_{\mathrm{MWP}}$ is WP fraction added to milk through MWP. 


\section{CONCLUSIONS}

The addition of increasing concentrations of MWP to milk led to slightly prolonged RCT and $\mathrm{k}_{20}$. In particular, MWP decreased the rapidity of $\mathrm{CN}$ aggregation during curd formation, which in turn led to delayed coagulation. No significant differences were detected for $\mathrm{a}_{30}$ across concentrations of MWP even if the tendency was for a weaker curd moving from control to samples with high levels of MWP. The fractions $\alpha$-LA and BSA showed a major recovery. Adjustments in cheese processing should be made when recycling MWP to optimize the potential of MWP as an ingredient in lowfat products. This could be achieved during coagulation by prolonging rennet activity before cutting the curd.

\section{ACKNOWLEDGMENTS}

A. Sturaro and A. Varotto conducted the experiment; A. Sturaro performed statistical analyses, wrote the first draft of the manuscript, and contributed to designing the trial; M. De Marchi designed the experiment; M. Penasa and M. De Marchi contributed to the discussion on data analysis and drafting the manuscript; M. Cassandro inspired the research, established the collaboration with the dairy industry, and was involved in reviewing the paper. All authors contributed to the discussion and commented on the work. The authors thank the dairy cooperative "Latteria di Soligo" (Farra di Soligo, Treviso, Italy) for financial support and for providing samples used in the study, and Elisa Zorzi (Latteria di Soligo, Farra di Soligo, Treviso, Italy) for technical assistance. This research was supported by Regione Veneto with the project "CheeseBull" (n. 2070868, Reg. CE 1698/2005, PSR del Veneto-DGR 1354 del 03/08/2011) and "Acquadolce" (n 1809089, Misura 124, PSR 2007-2013-DGR n. 745 del 15.03.2010).

\section{REFERENCES}

Aziznia, S. A., A. Khosrowshahi, A. Madadlou, and J. Rahimi. 2008. Whey protein concentrate and gum tragacanth as fat replacers in non-fat yogurt: Chemical, physical, and microstructural properties. J. Dairy Sci. 91:2545-2552.

Casal, E., A. Montilla, F. J. Moreno, A. Olano, and N. Corzo. 2006. Use of chitosan for selective removal of $\beta$-lactoglobulin from whey. J. Dairy Sci. 89:1384-1389.

Cassandro, M., A. Comin, M. Ojala, R. Dal Zotto, M. De Marchi, L. Gallo, P. Carnier, and G. Bittante. 2008. Genetic parameters of milk coagulation properties and their relationships with milk yield and quality traits in Italian Holstein cows. J. Dairy Sci. 91:371-376.

Chen, L., G. E. Remondetto, and M. Subirade. 2006. Food proteinbased materials as nutraceutical delivery systems. Trends Food Sci. Technol. 17:272-283.

Comin, A., M. Cassandro, S. Chessa, M. Ojala, R. Dal Zotto, M. De Marchi, P. Carnier, L. Gallo, G. Pagnacco, and G. Bittante. 2008.
Effects of composite $\beta$ - and $\kappa$-casein genotypes on milk coagulation, quality, and yield traits in Italian Holstein cows. J. Dairy Sci. 91:4022-4027.

de Faria, J. T., V. P. Rodrigues Minim, and L. A. Minim. 2013. Evaluating the effect of protein composition on gelation and viscoelastic characteristics of acid-induced whey protein gels. Food Hydrocoll. 32:64-71.

De Marchi, M., G. Bittante, R. Dal Zotto, C. Dalvit, and M. Cassandro. 2008. Effect of Holstein-Friesian and Brown Swiss breeds on quality of milk and cheese. J. Dairy Sci. 91:4092-4102.

De Marchi, M., R. Dal Zotto, M. Cassandro, and G. Bittante. 2007. Milk coagulation ability of five dairy cattle breeds. J. Dairy Sci. 90:3986-3992.

De Marchi, M., C. C. Fagan, C. P. O'Donnell, A. Cecchinato, R. Dal Zotto, M. Cassandro, M. Penasa, and G. Bittante. 2009. Prediction of coagulation properties, titratable acidity, and $\mathrm{pH}$ of bovine milk using mid-infrared spectroscopy. J. Dairy Sci. 92:423-432.

De Marchi, M., V. Toffanin, M. Cassandro, and M. Penasa. 2013. Prediction of coagulating and noncoagulating milk samples using mid-infrared spectroscopy. J. Dairy Sci. 96:4707-4715.

De Marchi, M., V. Toffanin, M. Cassandro, and M. Penasa. 2014. Invited review: Mid-infrared spectroscopy as phenotyping tool for milk traits. J. Dairy Sci. 97:1171-1186.

de Wit, J. N. 1998. Marschall Rhône-Poulenc Award Lecture: Nutritional and functional characteristics of whey proteins in food products. J. Dairy Sci. 81:597-608.

Formaggioni, P., M. Malacarne, A. Summer, E. Fossa, and P. Mariani. 2001. Milk with abnormal acidity. VI. The role of phosphorus content and the rennet-coagulation properties of Italian Friesian herd milks. Ann. Fac. Med. Vet. Univ. Parma 21:261-268.

Guinee, T. P., M. A. Fenelon, E. O. Mulholland, B. T. O'Kennedy, N. O'Brien, and W. J. Reville. 1998. The influence of milk pasteurization temperature and $\mathrm{pH}$ at curd milling on the composition, texture and maturation of reduced fat Cheddar cheese. Int. J. Dairy Technol. 1:1-10.

Guinee, T. P., C. B. Gorry, D. O'Challaghan, B. T. O'Kennedy, N. O'Brien, and M. A. Fenelon. 1997. The effects of composition and some processing treatments on the rennet coagulation properties of milk. Int. J. Dairy Technol. 50:99-106.

Gulzar, M., S. Bouhallab, R. Jeantet, P. Schick, and T. Croguennec. 2011. Influence of $\mathrm{pH}$ on the dry heat-induced denaturation/aggregation of whey proteins. Food Chem. 129:110-116.

Guyomarc'h, F., M. Nono, T. Nicolai, and D. Durand. 2009. Heatinduced aggregation of whey proteins in the presence of k-casein or sodium caseinate. Food Hydrocoll. 23:1103-1110.

Hinrichs, J. 2001. Incorporation of whey proteins in cheese. Int. Dairy J. 11:495-503.

Ikonen, T., K. Ahlfors, R. Kempe, M. Ojala, and O. Ruottinen. 1999. Genetic parameters for the milk coagulation properties and prevalence of noncoagulating milk in Finnish dairy cows. J. Dairy Sci. 82:205-214.

Ikonen, T., S. Morri, A.-M. Tyrisevä, O. Ruottinen, and M. Ojala. 2004. Genetic and phenotypic correlations between milk coagulation properties, milk production traits, somatic cell count, casein content, and pH of milk. J. Dairy Sci. 87:458-467.

Ismail, M., E. Ammar, and R. El-Metwally. 2011. Improvement of low fat mozzarella cheese properties using denatured whey protein. Int. J. Dairy Technol. 64:207-217.

Janhøj, T., C. B. Petersen, M. B. Frøst, and R. Ipsen. 2006. Sensory and rheological characterization of low-fat stirred yogurt. J. Texture Stud. 37:276-299.

Karaca, O. B., M. Guven, K. Yasar, and S. Kaya. 2009. The functional, rheological and sensory characteristics of ice creams with various fat replacers. Int. J. Dairy Technol. 62:93-99.

Koca, N., and M. Metin. 2004. Textural, melting and sensory properties of low-fat fresh kashar cheeses produced by using fat replacers. Int. Dairy J. 14:365-373.

Lo, C. G., and E. D. Bastian. 1998. Incorporation of native and denatured whey proteins into cheese curd for manufacture of reduced fat, Havarti-type cheese. J. Dairy Sci. 81:16-24. 
Lucey, J. A., M. Tamehana, H. Singh, and P. A. Munro. 1998. Effect of interaction between denaturated whey proteins and casein micelles on the formation and rheological properties of acid skim milk gels. J. Dairy Res. 65:555-567.

Nicolai, T., and D. Durand. 2007. Protein aggregation and gel formation studied with scattering methods and computer simulations. Curr. Opin. Colloid Interface Sci. 12:23-28.

O'Callaghan, D. J., C. P. O'Donnell, and F. A. Payne. 2002. Review of systems for monitoring curd setting during cheesemaking. Int J. Dairy Technol. 55:65-74.

Penasa, M., M. Cassandro, D. Pretto, M. De Marchi, A. Comin, S Chessa, R. Dal Zotto, and G. Bittante. 2010. Short communication: Influence of composite casein genotypes on additive genetic variation of milk production traits and coagulation properties in Holstein-Friesian cows. J. Dairy Sci. 93:3346-3349.

Penasa, M., F. Tiezzi, A. Sturaro, M. Cassandro, and M. De Marchi. 2014. A comparison of the predicted coagulation characteristics and composition of milk from multi-breed herds of Holstein-Friesian, Brown Swiss and Simmental cows. Int. Dairy J. 35:6-10.

Politis, I., and K. F. Ng-Kwai-Hang. 1988. Effects of somatic cell counts and milk composition on the coagulating properties of milk. J. Dairy Sci. 71:1740-1746.

Pretto, D., M. De Marchi, M. Penasa, and M. Cassandro. 2013. Effect of milk composition and coagulation traits on Grana Padano cheese yield under field conditions. J. Dairy Res. 80:1-5.

Riddell-Lawrence, S., and C. L. Hicks. 1989. Effect of curd firmness on stirred curd cheese yield. J. Dairy Sci. 72:313-321.

Roufik, S., P. Paquin, and M. Britten. 2005. Use of high-performance size exclusion chromatography to characterize protein aggregation in commercial whey protein concentrates. Int. Dairy J. 15:231241.

Rynne, N. M., T. P. Beresford, A. L. Kelly, and T. P. Guinee. 2004. Effect of milk pasteurization temperature and in situ whey protein denaturation on the composition, texture and heat-induced functionality of half-fat Cheddar cheese. Int. Dairy J. 14:989-1001.

Sahan, N., K. Yasar, A. A. Hayaloglu, O. B. Karaca, and A. Kaya 2008. Influence of fat replacers on chemical composition, proteolysis, texture profiles, meltability and sensory properties of low-fat Kashar cheese. J. Dairy Res. 75:1-7.

Spiegel, T., and M. Huss. 2002. Whey protein aggregation under shear conditions - Effects of $\mathrm{pH}$-value and removal of calcium. Int. J. Food Sci. Technol. 37:559-568.

Summer, A., M. Malacarne, F. Martuzzi, and P. Mariani. 2002. Structural and functional characteristics of Modenese cow milk in Parmigiano-Reggiano cheese production. Ann. Fac. Med. Vet. Univ. Parma 22:163-174.

Tiezzi, F., D. Pretto, M. De Marchi, M. Penasa, and M. Cassandro. 2013. Heritability and repeatability of milk coagulation properties predicted by mid-infrared spectroscopy during routine data recording, and their relationships with milk yield and quality traits. Animal 7:1592-1599.

Torres, I. C., T. Janhøj, B. Ø. Mikkelsen, and R. Ipsen. 2011. Effect of microparticulated whey protein with varying content of denatured protein on the rheological and sensory characteristics of low-fat yoghurt. Int. Dairy J. 21:645-655.

Yilsay, T. O., L. Yilmaz, and A. A. Bayizit. 2006. The effect of using a whey protein fat replacer on textural and sensory characteristics of low-fat vanilla ice cream. Eur. Food Res. Technol. 222:171-175. 